\title{
Why did Paul make so little \\ of the birth of Jesus?
}

\section{W A Sebothoma \\ Universily of South Africa}

\begin{abstract}
Why did Paul make so little of the birth of Jesus?

The parameters of the question in the title involve a comparative study of 'the birth of Jesus', its historicity or function within the synoptic tradition. The results are weighed against Pauline theology, its thrust as well as conceptual range. The pre-existent aspect of the notion of Messiah, which constitutes the condition for the possibility of the infancy narratives, is scrutinized in order to determine the validity or otherwise of the 'report' on 'the birth of Jesus'.
\end{abstract}

\section{INTRODUCTION}

The question: 'Why did Paul make so little of the birth of Jesus?' can be divided into two parts, namely: (a) The question of the point of departure for Pauline theology, as well as an inquiry into whether or not such point of departure may be responsible for Paul bypassing the story of the birth of Jesus, and (b): An investigation into the concept 'the birth of Jesus' in order to determine whether it represents an historical occurrence or a mere theological idea. If the latter were the case, then we will have to determine whether or not such a theological idea has an equivalent in the corpus Paulinum. Incidentally, the account of the birth of Jesus is found only in the gospels of Matthew and Luke. We might as well ask why Mark made so little of the birth of Jesus? We might go still further to ask why, in their reconstruction of $Q$, commentators make so little of the birth of Jesus? And since the Pauline letters, the $Q$ source and Mark are generally dated quite earlier than Matthew and Luke, has the date variable anything to do with the development of the concept of 'the birth of Jesus'? Did the idea of the birth of Jesus suddenly become fashionable at a certain period of time? These, and many other questions need to be asked, even if only to psychologically prepare ourselves for the progress as well as the outcome of our investigations. For purposes of clarity we will begin

\footnotetext{
- This article was published under a slightly different form: Waarom het Paulus so min gemaak van die geboorte van Jesus, in Swanepoel, F A (ed): Kersfees: Gister, vandag en môre. CB PowellBybeisontrum, UNISA (1992).
} 
with the (b) part of the question, namely an investigation into the concept of 'the birth of Jesus', before moving to the (a) part of the question, namely the Pauline theology. But first, something about the gospels, of which the infancy narratives are a part.

\section{THE FORMATION OF THE GOSPELS}

Paradoxically, one may speak of the Gospels as developing backwards in time, interweaving units of tradition (or interpreted facts?) in their stride. That is not the case with history, when viewed as a systematic recording of public events. The former (i e tradition) may include the latter (i e history), but the latter may not include the former without qualification.

The oldest Christian preaching about 'Jesus tradition' had as its core the kerygma (or Jesus passion, death and resurrection). Such 'dogma's' which are the cradle of Christian faith can be discerned from stereotypes or formulae in Acts 2:23, 32, Acts 3:14-15, Acts 4:10, Acts 10:39-40 and 1 Corinthians 15:3-4, among others. For the first preachers of the gospel, not only did these events constitute the clearest instance of God's conscious intervention in history or rather God's saving act through Jesus of Nazareth, on the one hand, but also that it was through the same events that the disciples eventually came to a more adequate understanding of just who this Jesus was (see Acts 2:33; cf Ezk 32:27), on the other (i e, contra prior knowledge presumed by the birth narratives).

With the passage of time, as the Christian communities became more and more conscious of themselves, the preaching was eventually shaped into an account of the passion, which constituted the oldest consecutive narrative about Jesus, so much so that some (e $\mathrm{g}$ Martin Kähler) saw in the gospel an extended passion narrative, while others (e g Zimmermann, Conzelmann) were more cautious by seeing the Gospel not merely as an extended passion, but also as testifying to the words and deeds of Jesus. This means that not only kerygma (or proclamation) but also didache (or teaching) were a major factor in the formation of the Gospel. If our argument is correct then Jesus derives authority to legitimate his teaching from the resurrection (de facto), rather than from some account of extraordinary birth 'report' (de jure). But the relationship between proclamation and teaching seems reminiscent of Deuteronomy 5 where the teaching of the Law is legitimated by the formula: 'I am Yahweh your God who brought you out of the land of Egypt out of the house of slavery' (Dt 5:6-7). Analogously, it can also be said that Jesus saved us from slavery to sin. 


\section{THE NATURE OF INFANCY NARRATTVES}

\subsection{The problem of corroborating witness}

For R E Brown, what distinguishes the infancy narratives from the rest of the gospel material is most probably tradition, anchored in the reminiscences of those who accompanied Jesus in his ministry, that is, from his baptism up till his death (Ac 1:22) and to whom he appeared after his resurrection (Ac 10:41; 1 Cor 15:3). In other words, if the readers of the gospel were to ask: how do you know that Jesus was baptized, or that he preached in Galilee, or that there was a Last Supper on the night before he died, or even that there was a trial, execution, death, burial and resurrection, they can reply that there was a Tradition passed about such things. Even Paul himself, who was probably not present at many of these events, clearly speaks of a tradition about such things (1 Cor 11:23; 15:3).

But do we have similar or common tradition about the birth of Jesus? How do we know what happened at Jesus' birth? Who are the witnesses of such birth? The apostles? Including Paul?

Some prefer to regard 'tradition' about Jesus' infancy as coming from Joseph or Mary. Yet Joseph, on the one hand, never appears during the ministry of Jesus and seems almost certainly to have died by that time (Beare 1981:285). Mary, on the other hand, does not seem to have been very close to the disciples of Jesus during the ministry (Mk 3:31-35; Mt 12:46-50; Lk 8:19-21; cf John 2:4). Indeed the body of the Gospel shows that the people among whom Jesus was reared as a child knew nothing about an extraordinary infancy (Mt 13:53-58; Lk 4:16-30; Mk 6:1-6).

Jesus' repudiation of his natural family ties (Mt 12:46-50) is incompatible with the extraordinary circumstances accorded his birth by the infancy narratives. In fact, the repudiation pericope reflects a tradition that 'the immediate family of Jesus, including even his mother, had no sympathy with his mission' which, on the redactional level, purports to derive directly from the extraordinary birth (Beare 1981:285). The tradition is reflected in the Markan account, to which Matthew returns after the interpolation of $Q$ material (Mt 12:31-37; [Mt 7:16-20]; Lk 6:43-45) and the use of $Q$ material to expand verses 38 to 45 (Schweizer 1978:295).

The tension evident in the material used by Matthew to compile his gospel raises serious questions about the genre or the nature of the infancy narratives: Are they on a par with the rest of the gospels? If not, do they enjoy a status of their own? This brings us to the next point in our discussion, namely an investigation into their composition. 


\subsection{The composition of infancy narratives}

\subsubsection{Points of difference}

There are abounding differences between Matthew's and Luke's accounts of the birth of Jesus. The genealogy in Matthew 1:1-17 is very unlike the genealogy that Luke has placed outside the infancy story 3:23-38. Moreover, the whole of Matthew 2:2-22 has no parallel in Luke, just as most of Luke chapter one, (apart from 1:2635) and most of chapter two of Luke has no parallel in Matthew. In Luke we are confronted with the story of Elizabeth, Zechariah and the birth of John the Baptist, the census which brings Joseph to Bethlehem, the acclamation of the shepherds, the presentation of Jesus in the temple as the parents return to Nazareth, and the loss and finding of the boy Jesus, at the age of twelve. Matthew recounts a different series of happenings of which Luke makes no mention: the star, the Magi, Herod's plot against Jesus, the massacre of the children at Bethlehem and the flight to Egypt. But if originally there was one narrative, how did it ever become fragmented into two different accounts we have now? Has any of events like census and massacre of children been corroborated by secular history? And if not, could the latter, that is, the massacre of children be an allusion to some tradition recorded in the Jewish Haggadah?1

\subsubsection{Points of agreement}

In the following items indicating agreement between Matthew and Luke we shall also try to indicate a possible source on which the evangelist depends.

* The parenthood of Mary and Joseph (Mt 1:18; Lk 1:27, 34). The parenthood of Mary and Joseph is taken for granted in the Synoptic tradition.

* Joseph is of Davidic descent (Mt 1:16, 20; Lk 1:27, 32; 2:4) Jesus' Davidic descent is taken for granted in the Synoptic tradition.

- The angelic announcement of forthcoming birth (Mt 1:20-23; Lk 1:30-35). See Judges 13:3f for an example of Old Testament pattern.

* Pregnancy not through normal human intercourse but ascribed to the Holy Spirit, which can also serve as agency for God (Mt 1:20,23, 25; Lk 1:34; Mt 1:18, 20; $\mathrm{Lk} 1: 35$ ). There is a vague parallel in Genesis 6:1-4, where the sons of God resorted to women and had children by them.

According to Westermann (1987:43-44), Genesis 6:1-4 is a narrative composed of two strands, where in verse 4a the culmination is the 'giants' (nepilim) and in verse $4 \mathrm{~b}$ the culmination is the heroes (gibborim). The former is an etiological note explaining the origin of giants, and the latter is a mythical narrative. 


\section{Context}

The context seems thematic: The Yahwistic narrator $(J)$ in chapters 1-11 of Genesis, brought together in the narratives of crime and punishment, two offenses by individuals (Gn 3-4) and two collective offenses (Gn 6:1-4; 11:1-9). Both the latter have to do with transgression of human limits. The offense in Genesis $11: 1-9$ is technological in origin, involving the building of a structure that reaches to the heavens, and in Genesis $6: 1-4$ it is the elevation of the genus humanum to a superhuman group as a result of a liaison between the 'sons of the gods' and women. Note that in the Near Eastern myth, probably of Canaanite origin, 'sons of the gods' (benêha elohim) refers not to angels but to divine beings.

This act of transgression demanding God's intervention is presupposed in Genesis 6:3. Surprisingly, the imposition of limits is not passed against the 'sons of the gods' but against the human race. Why? This is so perhaps because reference to humans as mere 'Flesh' does not equate the latter with sin, but rather sin as taking advantage of the helplessness of humans as 'Flesh'. The Leitmotif is therefore salvation as the goal of creation.

\section{Conclusion}

If our analysis is correct, then the idea of pregnancy through the agency of the Holy Spirit in the infancy narratives alludes to the process of salvation as consisting in the restorative elevation of the human race to divine status, conversely the elimination of human limitations. This can be achieved through the advent of a divine, if heavenly, pre-existent Messiah who is re-born on earth constituting Immaneul (Is 7:14), or God-with-us (Mt 1:23).

Intertextuality in this instance means simply that the human child in the text of Isaiah has a sign-value of 'divine presence' contemplated by the mythical child-figure in Matthew. But the latter has origins comparable to that of heroes in Genesis 6:1-4. Myth has a tendency of integrating all realms of reality, both mundane and extra-mundane (cf the role of Prometheus in Greek mythology).

- The naming of the child by the angel's directive (Mt 1:21; Lk 2:11). For the angelic announcement see third asterisk above. But Matthew 1:23 seems a modification of Isaiah 7:14 where the naming is also linked to the vocation of the person so named, namely Immanuel.

- The angel states that Jesus is to be Saviour (Mt 1:21; Lk 2:11). See our own comment above.

- The birth take place only after the parents have come to live together (Mt 1:2425; Lk 2:5-6). 
- The birth takes place at Bethlehem (Mt 2:1; Lk 2:4-6).

- The birth is chronologically related to the reign of Herod the Great (Mt 2:1; Lk $1: 5)$.

- The child is reared at Nazareth (Mt 2:23; Lk 2:39). The latter information is taken for granted in the synoptic tradition.

It is striking that all but the last of the items mentioned above are found in one section of the Matthean narrative (Mt 1:18-2:1). Is Luke dependent on Matthew?

\subsection{The role of the infancy narratives}

\subsubsection{The interpretation of the infancy narratives}

There are key points to be taken into account when interpreting the infancy narratives: Our focus is on Matthew 1:18-25. The form of the text of verses $20 \mathrm{f}$ assumes the schema of 'birth announcement' already shaped in the Old Testament (cf Gn 16:7-12; 17:19; Jd 13:3-5; Is 7:14). Luke is also familiar with it. It is quite probable that not only the introductory phrase of verse 22 , but also the quotation itself about the naming of Jesus as Immanuel (cf Isaiah 7:14) may be due to Matthew himself who generally quotes the Old Testament to the LXX text if he is not following sources (Luz 1985:116). Further, there could be a close parallel between Matthew 1:18-25 and 21:1-7 with regard to their being determined by the fulfillment formula (Pesch 1967:79).

\subsubsection{Conclusion}

What then can we conclude from the analysis above, concerning the role the infancy narratives had for the early Christian understanding of Jesus? For Brown (1976:8) 'God has made Himself present to us in the life of His Messiah who walked on this earth, so truly present that the birth of the Messiah was the birth of God's son'.

For Luz (1989:118), 'it is part of the attempt of Jewish-Christian communities to witness to the faith in Jesus, who was appointed as son by God according to his Spirit ( $\mathrm{Rm} \mathrm{1:4)} \mathrm{in} \mathrm{analogy} \mathrm{to} \mathrm{other} \mathrm{ancient} \mathrm{narratives} \mathrm{in} \mathrm{the} \mathrm{form} \mathrm{of} \mathrm{infancy}$ narratives. The virgin birth then belongs to the means for witnessing to the faith and has no direct historical background'. A form of kerymatic narrative?

\section{WHY DID PAUL MAKE SO LITTLE OF THE BIRTH OF JESUS?}

\subsection{Introduction}

Regarding the question: 'Why did Paul make so little of the birth of Jesus?' we refer the reader to our introduction, where we suggested that the answer will depend on whether the concept: 'birth of Jesus' refers to an historical occurrence or a theo- 
logical idea. From our analysis of the concept, it would appear that if the evangelists had intended the birth narratives to be understood as history, they would not have included a double genealogy which is incompatible with the virgin conception. Apologetic arguments have failed to win support. This leaves us with the second alternative, namely that of regarding the infancy narratives as a means of transmitting a theological idea. From the conclusions of both Brown and Luz, the message of such an idea could be the 'Sonship of Jesus' or his divinity. We have also seen how the evangelists arrived at this truth of the divinity of Jesus, namely by working backwards from the resurrection, as part of the general formation of the gospels. The statement of question at this juncture is whether Paul defended the Sonship of Jesus as did the infancy narratives. If he did, then we shall be forced to conclude that Paul made so little of the birth of Jesus, precisely because he defended the same message via a different route. Which route?

\subsection{The point of departure for Pauline theology}

\subsubsection{Paul's faithfulness to tradition}

What Paul proclaimed was in all essentials the apostolic kerygma (Acts 2:22), namely that Christ had been crucified and had risen from the dead in accordance with what the scriptures foretold (1 Cor 2:2; 15:3-4; Gal 3:1). What Paul calls 'his' Good News (Rm 2:16; 16:25) was indeed identical with the faith that was commonly held (Gal 1:16; 2:7-9). He not only accepted (1 Cor 11:23) but at times appealed to apostolic authority (1 Cor 15:3-7).

\subsubsection{Paul's innovative originality as proclaimer of the gospel}

Paul's originality as proclaimer of the Good News appears to have developed from his apologia, his presentation of his mission which eventually became a panoramic view of how his gentile mission fits into God's total plan for salvation (Stendahl 1977:4). The centrifugal force of his famous dictum of justification through faith has, as its Sitz im Leben, the relation between the Jews and Gentiles from which it should never be separated, under pain of distortion. An example of such distortion is the unfortunate polarization of grace and law, out of context, and projected as though grace were corollary to justification through faith alone, that is apart from 'works' of the law. And yet the actual polarization was between the Levitical philosophy of Law ( $R m$ 10:5) engendering an act-centered morality based on the merits of personal effort (Lv 8:5ff) on the one hand, over against the Deuteronomistic interpretation of Law (Rm 10:6), based on the precept of love (cf Dt 30:6, 16, 20) or the circumcision of the heart, engendering a value centered morality, on the other. The 
latter perspective is one in which grace and law are given together under one package, as it were. The same view is delineated eloquently by James' reference to 'living' faith (Jm 2:14-26).

The point we are trying to demonstrate is that the whole of Paul's ministry was preoccupied with practical, pastoral work, and as such was a far cry from arm chair theological tractates, or devotional reflections about 'the birth of Jesus'. Not that Paul was unconcerned about Jesus as a person, no!

He preached Jesus; nay, Jesus crucified - where the crucifixion and resurrection were two sides of the same salvific coin, offered in purchase of the kingdom of God. The Pauline christology is uniquely embedded in ecclesiology: Thus the 'body of Christ' theology presents dogma (or Indikativ) and ethics (or Imperativ) in one indivisible mould which can deal effectively (or so he thought) with pastoral issues and practical problems of the nascent Christianity. Yet we have to concede that the imaginative narratology concerning the birth of Christ also represents an answer to pastoral needs arising no less than a generation later: Legends and myths tend to embellish memories of heroes gone by, heroes who are raised as examples of cultural values in any community. The same thing happened with Moses; why should Jesus of Nazareth be an exception? Memories can thus be said to re-write history.

Paul's reference to 'the truth of the gospel' (Gl 2:5) implies that truth entails existential reception so that one can speak of the performative aspect of truth (Husinger 1993:41). This means that 'truth' describes that relationship whereby the form of life corresponds to 'reality' in a sense that 'neither the mind nor the sentence can correspond to reality in a some independent or non-mediated way' (Husinger 1993:43). Bultmann's original thesis on the Pauline ethics (cf Das Problem der Ethik bei Paulus: [1924] 1967 in Bultmann, $R$ Exegetica: hrsg von $E$ Dinkler) was recently defended by Gräbe (1990:54-66).

Lastly, the starting point for Paul's theologizing was the Damascus experience (Ac 9:3-5) in which he encountered the risen Lord. The resurrection, therefore, (as opposed to 'the birth of Jesus') constituted the starting point for specifically Christian faith (1 Cor 15:13, 14).

\subsection{Did Paul explicitly defend the Sonship or divinity of Jesus as did the infancy narratives?}

The focus of our study will be Romans 1:3, 4, where Paul speaks of the gospel concerning his (God's) Son, who was descended from David according to the flesh and designated Son of God in power according to the Spirit of holiness by his resurrection'. 


\subsubsection{The Status Quaestionis}

The statement of question is: What is the role of the resurrection in the life of Jesus of Nazareth? In other words, what is the status of Jesus before the resurrection, and, what is the status of Jesus after the resurrection?

\subsubsection{The remote context of Romans $1: 3,4$}

4.3.2.1 The inter-textuality of the post resurrection language as a strategy for Messianic pre-existence

We have already noted that in his preaching Paul was faithful to the tradition handed down to him ( 1 Cor 15:1,3), the content of which was the death and resurrection of Jesus (verse 4f).

Our thesis at this juncture is that the notion of Messiah appears to have connotations of pre-existence. Peter's speech at Pentecost (Ac 2:14-36), in which he pleads that Jesus be recognized for what he is, namely the Messiah, concludes the argument from scripture thus: It is by his resurrection that Jesus has been constituted 'Lord' of whom David in Psalm 110 said:

The Lord (Yahweh) declared to my Lord (Messiah)

take your seat at my right hand

till I have made your enemies

Your footstool.

Psalm 16, also quoted by Peter in the same speech (Ac 2:25-28) puts the whole picture of the Messiah within the context of a yearning for union with God that defies even death: a vague dream of the resurrection? It should be born in mind that the psalms were attributed to David (9-8th century BC). This means that David, through the psalms, spoke of the Messiah in the past tense. Luke in 3:22 is probably quoting Psalm 2:7: 'You are my Son; today I have fathered you'. It is a messianic enthronement psalm which appears to equate enthronement with 'begetting' by God. In other words, the act of God in fathering the Messiah, is at the same time enthronement. This is the intertextuality from which Romans 1:3-4 should be understood, where Paul speaks of Jesus as designated Son of God in power. In both Luke and Paul the Spirit of holiness or Holy Spirit is God's agency for begetting. The occasion, however differs: In Paul it is the resurrection and in Luke it is the baptism. The point we are trying to make is that the resurrection must be understood in terms of enthronement and/or begetting. But the latter, that is, enthronement and begetting, also imply pre-existence associated with divinity. So for example, Paul elsewhere speaks of Christ as the power and the wisdom of God (1 Cor 1:24). The context of Paul's allegation is his distinction between true wisdom 
and false wisdom. John, however, will make an association between Jesus and wisdom in John 6:35 where Christ's gift of himself as the bread of life is reminiscent of Wisdom inviting all people to her table (Pr 9:1-6). But Jesus as the bread of life is to be contrasted with manna given during Israel's sojourn in the desert. Proverbs 8:22-3 speaks of Wisdom as saying: 'Yahweh created me, first-fruits of his fashioning, before the oldest of his works. From everlasting I was firmly set...I was beside the master craftsman'. In other words, Wisdom was co-creator with God in terms reminiscent of the Word of John 1:1-3.

In conclusion, we may safely assume that Paul's idea of Messiah was firmly grounded in the contemporary messianism of pre-Christian Judaism centered in the offices of king, priest and prophet. For Schürer ([1885-1924]; 1979:518-519), Jewish messianic expectations can be conclusively documented as having 'regarded the Messiah as a fully human individual, a royal figure descended from the house of

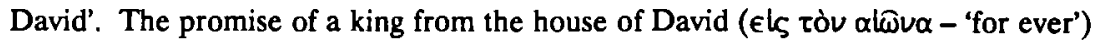
means simply that the dynasty is not to die out. Similarly, Simon Maccabaeus was chosen by the people as Prince and High Priest 'for ever' (1 Mac 14:41), where these titles are effectively declared hereditary in his family.

Of significance however, is the concretization of biblical theology in the traditions of the Qumran sect. Messianism appears to be approached from two models:

(a) as a human figure that is raised to the supernatural level, or

(b) as a supernatural figure that descends to the level of mere humans.

Both models have messianic pre-existence as a common denominator. (Note that pre-existence in the realm of eternity is not equivalent to 'endless time', but rather outside of 'time and space' that characterized the first moment of creation in Genesis.) What compounds the problem of messianism further, is the fact that despite the singular form of this title, the Damascus Document testified to the doctrine of $t w o$ Messiahs; one inspired by secular views and the other by religious prerogatives (Schürer 1979:552). Did the sacerdotal messianism coalesce with the traditional Davidic promise around the Hasmonean period as Schürer alleges?

\section{Model a:}

According to Model $a$ the Messiah was generally thought of as an earthly king and ruler, but one also endowed by God with special gifts and powers. In the Psalms of Solomon he appears as entirely human king (Ps 17:23, 47) righteous and learned (Ps 17:35) free from sin and holy (Ps 17:41, 46) and endowed by the holy spirit with power, wisdom and righteousness (Ps 17:42; Schürer 1979:519). 
From this picture, the only way for the Messiah to acquire supernatural powers proper to his office is through an extraordinary event like the resurrection, through which he will then automatically become pre-existent.

\section{Model b:}

In 4 Ezra and the Parable of Enoch, the Messiah appears already in his supernatural realm of pre-existence and the powers, as well as prerogatives that go with such a status (Schürer 1979:519).

Yet the Qumran sect knew of another High Priest, but in this case one who was also angelic deliverer, namely the heavenly Melkizedek. According to Schürer (1979:553), this is a figure which may have contributed substantially to New Testament christological ideas'. The document in question is a midrashic fragment, and is eschatological in content.

If Schürer's allegations are anything to go by, then the infancy narratives in Matthew and Luke, as well as the incarnation in the prologue of John all proceed from Model $b$ as a point of departure for theologizing.

But why the contrasting models of the Messiah?

An 'either-or' opposition between the biblical account of creation (which by definition also implies salvation) on the one hand, and a scientific explanation of the world (where history implies a scientific, logical explanation) on the other, is unnecessary. Why?

For Westermann (1987:12-13) the relationship of Genesis 1 to the Bible as a whole, that is, the history of the people of God, which begins with the patriarchs ( $G$ n 12-50) and Exodus, (or the trek from Egypt) and extends through the history of the Israelites to Christ and his apostles, finds in Genesis a framework that links this history to the beginnings of time, the world and the human race. Thus everything in it is based on this beginning. But as Genesis 1 already anticipates a goal for humankind, so the Bible, both Old- en New Testaments, tells of the final event that includes the whole of humanity as well as the rest of creation, and brings them to the goal destined by the Creator.

Hebrew thought that underlies biblical language can speak in paradoxes and contrasts. It is perhaps a measure of unfathomability of the mystery of God, that creation, which proceeds from him, can be spoken of only in the harmony of many including contrasting) voices of generations stretching through history.

Model $b$ then lends itself to the only language that can handle the ineffable (or the unfathomable), that is, poetry and myth. The same is true, as we have seen, with the parallel in Genesis 6:1-4. And although according to our analysis Pauline theology was grounded on the presuppositions of Model $a$, that is the human 
Messiah, Paul nevertheless did not shy away from accommodating Model $b$ (e g, the pre-Pauline hymn in $\mathrm{Phl}$ 2:6-11) in his theology. This hymn could possibly have represented an early kerygmatic confession (Fitzmyer 1968:250). The impact of the resurrection might have been so overwhelming, that history was contextualised and re-written into new kerymatic narratives like the gospels, for purposes of preaching.

\subsubsection{The immediate context of Romans 1:3,4}

Now that we are familiar with pre-existent connotations in the concept of Messiah, we re-capitulate the statement of question, namely the role of the resurrection in Jesus' life. In the immediate context of our passage, Paul is called, or 'set apart for God's gospel' which was foretold in the scriptures.

\subsubsection{The status of Jesus before the resurrection}

Jesus was 'descended from David, according to the flesh'. This means that Jesus was physically or biologically of 'Davidic descent'. This gave him a right to the sacral anointing of a Davidic heir. Jesus could be called 'son of David'. And since David could be called son of God, Jesus could also be called son of God.

\subsubsection{The status of Jesus after the resurrection}

The phrase 'concerning his Son' refers to God's gospel and the promises made by him in the Old Testament refer to Jesus, who stands in a unique relation to God as 'his Son' (Rm 8:3, 32; Gl 4:4).

The phrase 'according to a Spirit of holiness' must be understood in contrast to 'according to the flesh' in 4.3.3.1 above, to underscore the role of the resurrection.

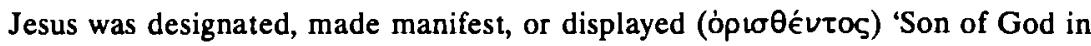
power' (Manson 1962:941). Jesus is equated with a Spirit of holiness. This same Spirit empowers Jesus for salvific work. In other words the Spirit characterizes the resurrection. It is the Spirit of total life, beyond death. It is a life-giving Spirit unto salvation. Jesus becomes the content of God's gospel foretold in the Old Testament.

\subsubsection{The Pauline idea of the resurrection}

The Pauline idea of the resurrection can be summed up in three moments:

* Christ rose from the dead only because God raised him (Rm 4:25; 10:9, cf Ac 2:24; 1 Cor $6: 14 ; 15: 15 ; 2$ Cor $4: 14$, Gl 1:1, 1 Ts $1: 10,1$ Pt 1:21), and thus displaying his (God's) power (Rm 6:4; 2 Cor 13:4). 
* And because God raised him to life ( $\mathrm{Rm} 8: 11)$ Christ is established in glory as kyrios (Phl 2:9-11; Ac 2:36; Rm 14:9) and thus deserving anew, this time in virtue of his messianic work, the name he had from eternity: 'Son of God' (Ac 13:33, cf Heb 1:1-5; 5:5; Rm 8:11; 9:5; see Allen 1986:1317).

* Since the pre-existence of Christ is retrospective by virtue of the resurrection of Jesus, the greatness of the incarnate Son of God (cf Heb 1:1-5) which is alluded to also by the virgin birth or the extraordinary circumstances ascribed to it, came to be incorporated in the Apostolic Creed.

\subsubsection{Conclusion}

What is peculiar about the infancy narratives is not that Jesus was born in history, but the non-historicality of the extraordinary circumstances attributed to that birth.

Paul was educated in the tradition that, among other things, regarded the Messiah as pre-existent. But by believing that Jesus was raised from the dead by God - so that he, by that fact was the Christ, Paul automatically accepted, along with Christian tradition Jesus' Sonship, or his unique relationship to God as Father. The latter 'unique relationship' was a status otherwise attested to through the extraordinary circumstances of the birth, described in the infancy narratives.

Once we understand the role of the infancy narratives, namely their witnessing to Jesus as Immanuel or God-with-us, in and through his only Son, then it becomes clear:

* that the infancy narratives are a means to an end (the transmission of a theological idea concerning the incarnate Son of God);

* that the end in question can be reached by other means (the proclamation of kerygma);

* that Paul made so little of the birth of Christ because he achieved the same goal through other means.

It is not surprising then, that the infancy narratives have been regarded as 'miniature gospels' in their own right, so that Mark is still a complete gospel without them.

\section{END NOTES}

1. The Jewish Haggadah mentions that the ancestors of Abraham lived in the time of Nimrod (cf Gn 10:8-9), representing prototype evil and rebellion against God. Nimrod, it is said, built the Tower of Babel. When he heard of the birth of Abraham, he ordered that all children be killed (cf Flavius Josephus, Antiquitates Iudiaca 154 and the Koran, Soura 21/52). 
Works consulted

Aland, K (ed) 1979. The synopsis of the four Gospels. Stuttgart: Biblia-Druck.

Beare, F W 1981. The gospel according to Matthew: A commentary. Basil: Blackwell.

Brown, R E 1977. The birth of the Messiah: Infancy narratives in Matthew and Luke. Garden City: Doubleday.

Fitzmyer J A, 1968. The Letter to the Romans. Englewood Cliffs: Prentice-Hall. (The Jerome Biblical Commentary.)

Gräbe, P J 1990. Die verhouding tussen indikatief en imperatief in die Pauliniese etiek: Enkele aksente uit die diskussie sedert 1924. Scriptura 32, 54-66.

Husinger, G 1993. Truth as self-Involving: Barth and Lindbeck on the cognitive and performative aspects of truth in theological discourse. Journal of the Academy of Religion LX1/1, 41-56.

Knox, J 1954. The epistle to the Romans. Nashville: Tenessee.

Cragg, G R 1978. The Acts of the Apostles. The epistle to the Romans, in Buttrick, G A (ed), The Interpreter's Bible, Vol IX. Nashville: Parthenon Press.

Lowther Clark, W K 1953. Concise Bible Commentary. New York: McMillan Co.

Luz, U 1985. Das Evangelium nach Matthäus, 1 Teilband, Mt 1-7. Zurich: Beziger Verlag.

Manson, T W 1962. Romans. Victoria: Thomas Nelson. (Peake's Commentary on the Bible.)

Pesch, R 1967. Eine alttestamentliche Ausfhrungsformel im Matthaus-Evangelium: Redaktionsgeschichtliche und exegetische Beobachtungen. Biblische Zeitschrift 11, 79-95.

Schürer, E 1979. The history of the Jewish people in the age of Jesus Christ, Vol II. Edinburgh: T \& T Clark.

Schweizer, E 1978. The good news according to Matthew. London: SPCK.

Stendahl K, 1977. Paul among Jews and Gentiles. London: SCM Press.

The New Jerusalem Bible, 1985. New York: Doubleday.

Westermann, C 1987. Genesis. A practical commentary: Text and interpretation. $\operatorname{Tr}$ by D E Green. Grand Rapids: Eerdmans. 